\title{
DAMPAK PEMBANGUNAN KAWASAN MEGAMAS MANADO TERHADAP KONDISI MASYARAKAT DI KELURAHAN WENANG SELATAN
}

\author{
Gratsia Valery Tumurang \\ Agnes E. Loho \\ Leonardus R. Rengkung
}

\begin{abstract}
This study aims to determine the impact due to the development of Megamas Regions on the condition of the community in South Wenang Urban Village. This study requires secondary data and primary data taken from kelurahan and community as respondents. Data collection is done by survey based on questionnaire compiled. The number of samples taken 30 respondents. The data analysis used in this research is descriptive analysis by explaining all aspects related to the impact caused by Megamas area development. Research results show that the development of Megamas Area gives the impact of both social and economic impact, beruba positive or negative impact. Some positive impacts are increased income and welfare, employment, business opportunities and recreation, while negative impacts are decreasing income, consumptive, commotion / discomfort, job loss and reduced hygiene. *Irr*.
\end{abstract}

Keywords: development impact, megamas area, Wenang Urban Village.

\begin{abstract}
ABSTRAK
Penelitian ini bertujuan untuk mengetahui dampak akibat pembangunan Kawasan Megamas terhadap kondisi masyarakat di Kelurahan Wenang Selatan. Penelitian ini memerlukan data sekunder dan data primer yang diambil dari kelurahan dan masyarakat sebagai responden. Pengambilan data dilakukan secara survei berdasarkan daftar pertanyaan yang disusun. Jumlah sampel yang di ambil 30 responden. Analisis data yang digunakan dalam penelitian ini adalah analisis deskriptif dengan menjelaskan semua aspek yang berkaitan dengan dampak yang ditimbulkan akibat pembangunan Kawasan Megamas. Hasil Penelitian menunjukkan bahwa pembangunan Kawasan Megamas memberikan dampak baik dampak sosial maupun ekonomi, beruba dampak positif maupun negatif. Beberapa dampak postif yang ditimbulkan adalah peningkatan pendapatan dan kesejahteraaan, penyerapan tenaga kerja, adanya kesempatan berusaha dan tempat rekreasi, sedangkan dampak negatif adalah penurunan pendapatan, konsumtif, keributan/tidak nyaman, kehilangan pekerjaan dan kebersihan berkurang. "Irr*.
\end{abstract}

Kata kunci: dampak pembagunan, kawasan megamas, Kelurahan Wenang Selatan.

\section{PENDAHULUAN}

\section{Latar Belakang}

Pembangunan merupakan suatu proses multidimensional yang meliputi perubahan dalam struktur sosial, perubahan dalam sikap hidup masyarakat dan perubahan dalam kelembagaan. Selain itu, pembangunan juga meliputi perubahan dalam tingkat pertumbuhan ekonomi, pengurangan ketimpangan pendapatan nasional, peningkatan kesehatan dan pendidikan serta pemberantasan kemiskinan. Dalam pembangunan tersebut terkadang suatu upaya yang terus menerus dilakukan oleh penduduk suatu daerah guna mencapai sarana kesejahteraan yang diinginkannya baik dalam jangka pendek (short run) maupun dalam jangka panjang (long run) (Sinarmata, 2012).

Tujuan pembangunan adalah untuk mensejahterakan masyarakat dalam suatu 
daerah atau wilayah, seperti penciptaan tenaga kerja dan pegurangan pengangguran. Jika kegiatan ekonomi dan keterkaitannya sesuai dengan sistem mekanisme pasar, maka keterkaitan antar berbagai aktivitas tersebut tidak menimbulkan masalah. Sebaliknya, jika keterkaitan antar kegiatan yang tidak melalui sistem mekanisme pasar maka akan menimbulkan masalah. Keterkaitan suatu kegiatan pembangunan dengan kegiatan lain yang menghasilkan dampak yang disebut dengan eksternalitas (Hudiyanto, 2005).

Kota Manado, sebagai ibukota Sulawesi Utara, menunjukkan perkembangan ekonomi yang sangat pesat dalam lima tahun terakhir. Hal ini dapat dilihat pada tingkat pertumbuhan ekonomi yang menunjukkan daya beli yang semakin meningkat. Peningkatan pertumbuhan ekonomi Kota Manado diakibatkan oleh beberapa faktor seperti terbukanya lapangan pekerjaan, infrastruktur yang semakin membaik, dan iklim investasi yang semakin terbuka. Semua faktor tersebut memberikan kontribusi yang sangat signifikan terhadap pembangunan dan pertumbuhan ekonomi Kota Manado. Salah satu bentuk pembangunan yang memberikan kontribusi terhadap perekonomian Kota Manado adalah pembangunan reklamasi Kota Manado yang diikuti dengan munculya pusatpusat perdagangan dan rekreasi.

Seiring dengan perkembangan peradaban, masyarakat membutuhkan lahan-lahan baru dalam kegiatan sosial ekonominya, sedangkan lahan yang ada di daratan semakin terbatas. Dengan keadaan seperti ini masyarakat mulai memanfaatkan wilayah pesisir untuk berbagai kepentingan, sehingga muncul permasalahan yang berkaitan dengan penyediaan lahan bagi aktifitas sosial dan ekonomi masyarakat. Untuk memenuhi tuntutan kebutuhan akan lahan, menjadikan usaha mereklamasi pantai sebagai salah satu konsekuensi logis bagi penyediaan lahan baru aktifitas sosial ekonomi masyarakat.

Oleh karena itu, wajar saja jika belakangan ini usaha untuk mereklamasi pantai semakin banyak bermunculan. Reklamasi pantai memiliki beberapa pengertian. Dari segi bahasa kata reklamasi berasa dari bahasa Inggris yaitu reclamation yang berarti pekerjaan memperoleh tanah. Jadi reklamasi pantai dapat diartikan sebagai pekerjaan untuk mendapatkan bidang lahan dengan luasan tertentu di daerah pesisir dan laut. Sedangkan menurut Hasni (2010), mengatakan bahwa reklamasi pantai merupakan suatu peralihan fungsi dari wilayah pantai menjadi sebuah wilayah daratan. Pengadaan reklamasi pantai pada umumnya dilakukan untuk menjadikan kawasan yang tidak bermanfaat menjadi kawasan yang mempunyai manfaat. Kawasan hasil reklamasi biasanya dimanfaatkan untuk kawasan pertanian, pemukiman, perindustrian, pertokoan atau bisnis dan obyek wisata. Kegiatan reklamasi ini juga dapat dimanfaatkan untuk keperluan konservasi wilayah pantai. Kegiatan ini dilakukan apabila suatu wilayah tererosi atau terabrasi cukup parah sehingga perlu dikembalikan seperti kondisi semua, karena lahan tersebut mempunyai arti bagi wilayah dan Negara. Bagi daerah, pengadaan reklamasi pantai juga dapat memberikan suatu ruang bagi Pemerintah Daerah untuk meningkatkan Pendapatan Asli Daerahnya dari tanah yang muncul sebagai hasil reklamasi pantai. Pemerintah mulai melegalkan adanya reklamasi didaerah-daerah yang dianggap dapat strategis untuk dilakukannya reklamasi pantai. Begitu pula dengan pemerintah Kota Manado yang mulai memperbolehkan sejumlah perusahaan untuk melakukan reklamasi disepanjang Kawasan Megamas Manado.

Reklamasi pantai Manado yang dilakukan sejak tahun 1996, memiliki tujuan, untuk menahan tingkat abrasi pesisir pantai Manado yang meningkat dari tahun ke tahun. Seiring dengan perkembangannya, maka muncullah beberapa investor dengan segala tujuan ekonominya untuk melanjutkan proses reklamasi pantai Manado dengan harapan akan dibangunnya pusat-pusat pertokoan, rumah makan, perdagangan, hiburan dan perbelanjaan. Dalam buku Profil Kota Manado tahun 2013, disebutkan bahwa sepanjang pesisir pantai Kota Manado telah tereklamasi sekitar hampir 85 persen dari keseluruhan yang ada. Dari total tersebut, berkisar 80 persen telah dibangun berbagai macam pusat perdagangan seperti, kios-kios/rumah makan, tempat hiburan, dan perbelanjaan. Munculnya berbagai macam aktivitas ekonomi tersebut memberikan 
dampak, terutama sosial ekonomi baik bagi pengunjung, para investor terutama bagi masyarakat.

Kawasan Megamas merupakan suatu kawasan reklamasi pantai seluas $36 \mathrm{Ha}$, yang dibangun dan kemudian dikembangkan oleh PT.Megasurya Nusalestari. Dari sejarahnya proses reklamasi sendiri dimulai tahun 1996, namun sempat terhenti pada tahun 1998 dikarenakan Krisis Moneter yang terjadi pada tahun itu. Konsep dari Kawasan Megamas adalah Kawasan Bisnis dan Pariwisata terpadu. Kawasan Megamas terletak di Jl. Piere Tendean (Boulevard) Manado, berbatasan dengan Kelurahan Wenang Selatan Kecamatan Wenang. Kelurahan Wenang Selatan merupakan daerah yang sebagian besar berdiri bagunan-bangunan, ruko-ruko tempat menjual barang maupun jasa. Kelurahan Wenang Selatan dipadati pertokoan, restoran, hotel, kantor, serta fasilitas umum yakni rumah sakit, tempat ibadah serta persekolahan. Data menunjukkan bahwa $60 \%$ wilayah kelurahan Wenang selatan di dominasi oleh tempat usaha, kantor, dan fasilitas umum.

Pada umumnya, masyarakat di Kelurahan Wenang Selatan merupakan masyarakat menengah kebawah, dan mayoritas mata pencaharian masyarakat Wenang Selatan adalah nelayan, karena dulunya daerah tersebut merupakan kawasan pinggiran pantai. Seiring berjalannya waktu dengan dibangunnya tempattempat usaha oleh investor maka terjadi perubahan dari segi sosial dan ekonomi masyarakat, kehilangan pekerjaan bagi nelayan.

Aspek sosial berkaitan dengan segala sesuatu yang berhubungan dengan aktivitas dan kehidupan masyarakat, sedangkan aspek ekonomi berarti sebagai ilmu yang berhubungan dengan kegiatan produksi, distribusi atau pemasaran, pemakaian barang serta kekayaan. Sekilas sosial dan ekonomi seperti dua hal dan cabang ilmu yang berbeda, namum diantara keduanya sebenarnya terdapat kaitan yang erat. Salah satu kaitan yang erat tersebut adalah jika ekonomi tidak terpenuhi maka akan terdapat dampak sosial yang terjadi di masyarakat.

Kajian tentang "Studi Amdal Analisis Dampak Reklamasi Pantai Kawasan Bahu Mall, Manado" menyimpulkan bahwa:

- Pada tahap kegiatan konstruksi lebih menimbulkan banyak dampak negatif bila dibandingkan dengan pada tahap yang lainnya. Dampak yang dihasilkan pada tahap konstruksi, lebih banyak ditimbulkan saat kegiatan mobilisasi alat dan bahan material pembangunan kawasan Bahu Mall. Hal tersebut menimbulkan perubahan pada lingkungan sekitar seperti adanya perubahan kualitas air laut, penurunan kualitas udara bersih, dan pendapatan nelayan yang semakin berkurang.

- Selain terdapatnya tahap yang menimbulkan dampak negatif, tahap kegiatan yang menimbulkan banyak dampak positif terdapat pada tahap kegiatan pra konstruksi dan pasca konstruksi. Hal tersebut terlihat pada tahap pra konstruksi saat perizinan penggunaan lahan dan pada tahap pasca konstruksi dimana pendapatan masyarakat sekitar menjadi meningkat.

- Perubahan sosial ekonomi masyarakat dan pembenahan kualitas air dan udara bersih merupakan dampak penting yang sangat perlu diperhatikan oleh pemerintah dan segera dilakukan pembenahan hingga tercapainya kesejahteraan masyarat. Dampak tersebut harus dilakukan pengelolaan dan pemantauan yang berpedoman pada RKL dan RPL yang telah dibuat untuk meminimalisir dampak penting yang ditimbulkan dari reklamasi kawasan Bahu Mall Manado.

Kajian antara sosial dan ekonomi memerlukan pendekatan yang rasional sehubungan dengan penentuan responden, yaitu keduanya saling mempunyai sifat ketergantungan. Berawal dari berhasilnya pembangunan ekonomi dan sosial masyarakat kiranya akan membawa pengaruh terhadap tingkat kesejahteraan masyarakat. Kesejahteraan inilah yang menjadi variabel objek yang sangat penting. Para ahli ekonomi melakukan pengukuran tingkat kesejahteraan dilihat dari variabel ekonomi yaitu tingkat pendapatan. Variabel ekonomi yang lain besarnya pengeluaran atau belanja atau konsumsi, baik pangan maupun non pangan serta tingkat produksi, investasi dan sebagainya. Sedangkan variabel sosial antara lain: tingkat pendidikan, etos kerja, jenis pekerjaan, kependudukan, dan sebagainya. 


\section{Rumusan Masalah}

Pembangunan Kawasan Megamas merupakan salah satu bagian dari kebijakan pemerintah terkait dengan reklamasi pantai Manado, yang diperkirakan juga memberikan kontribusi dalam perkonomian Kota Manado, khususnya pada sektor perdagangan. Adanya pembangunan kios-kios makan tersebut, diduga memberikan dampak sosial ekonomi, seperti adanya peningkatkan pendapatan masyarakat, dan penyerapan tenaga kerja. Sosial berarti segala sesuatu segala sesuatu yang berkenan dengan masyarakat. Sedangkan ekonomi berarti ilmu yang mengenai asas-asas produksi, distribusi dan pemakaian barang-barang serta kekayaan (seperti keuangan, perindustrian, dan perdagangan). Berdasarkan uraian ini maka yang menjadi masalah dalam penelitian ini adalah bagaimana pembangunan Kawasan Megamas terhadap kondisi ekonomi masyarakat di sekitar Kelurahan Wenang Selatan.

\section{Tujuan Penelitian}

Tujuan penelitian ini adalah untuk mengetahui dampak sosial ekonomi akibat pembangunan Kawasan Megamas terhadap kondisi masyarakat di Kelurahan Wenang Selatan.

\section{Manfaat Penelitian}

Manfaat yang diharapkan dalam penelitian ini adalah untuk memberikan informasi pada semua kelembagaan terkait, khususnya pemerintah Kota Manado tentang dampak pembangunan Kawasan Megamas terhadap kondisi masyarakat di Kelurahan Wenang Selatan.

\section{METODE PENELITIAN}

\section{Waktu dan Tempat Penelitian}

Penelitian ini dilakukan pada bulan Februari sampai bulan April 2018 dan berlokasi di Kecamatan Wenang Selatan, Kota Manado.

\section{Metode Pengumpulan Data}

Penelitian ini memerlukan data dalam bentuk data sekunder dan data primer yang diambil dari kelurahan dan masyarakat sebagai responden. Pengambilan data dilakukan secara survei berdasarkan daftar pertanyaan yang disusun. Jumlah sampel yang di ambil 30 responden.

\section{Pengukuran Variabel}

Variabel yang diukur dalam penelitian ini adalah terkait dengan besaran partisipasi masyarakat Kelurahan Wenang Selatan. Pengukuran variable dalam penelitian ini dikategorikan dalam 2 aspek yaitu pengukuran aspek dampak positif dan aspek dampak negatif dan dapat dijelaskan sebagai berikut:

1. Karakteristik responden

2. Jenis Kelamin

3. Umur

4. Tingkat Pendidikan

5. Pekerjaan

6. Pendapatan

7. Sikap masyarakat

8. Dampak yang ditimbulkan baik positif maupun negatif

\section{Analisis Data}

Analisis data dalam penelitian ini dilakukan secara deskriptif dengan menjelaskan semua aspek yang berkaitan dengan dampak yang ditimbulkan akibat pembangunan Kawasan Megamas.

\section{HASIL DAN PEMBAHASAN}

\section{Gambaran Umum \\ Kelurahan Wenang Selatan}

Gambaran umum lokasi penelitian merupakan tempat dilakukannya penelitian, dimana lokasi penelitian bertempat di Kelurahan Wenang Selatan. Gambaran umum lokasi penelitian yang dijelaskan pada bagian ini meliputi keadaan geografis dan kondisi sosial ekonomi kependudukan di Kelurahan Wenang Selatan. 
Adapun letaknya menurut Geografi dibatasi antara lain oleh:

a) Sebelah Utara: Wenang Utara Lingk. 6

b) Sebelah Selatan: Titiwungen Utara

c) Sebelah Barat: Teluk Manado

d) Sebelah Timur: Wenang Utara Lingk. 1

Kelurahan Wenang Selatan merupakan daerah yang sebagian besar berdiri bagunanbangunan, ruko-ruko tempat menjual barang maupun jasa. Kelurahan Wenang Selatan sangat dipadati oleh sejumlah pertokoan, restoran, hotel, kantor, serta fasilitas umum yakni rumah sakit, tempat ibadah serta persekolahan. Data menunjukkan bahwa $60 \%$ wilayah kelurahan Wenang selatan di dominasi oleh tempat usaha, kantor, dan fasilitas umum.

Pada umumnya, masyarakat di Kelurahan Wenang Selatan merupakan masyarakat menengah kebawah, dan mayoritas mata pencaharian masyarakat Wenang Selatan adalah nelayan, karena dulunya daerah tersebut merupakan kawasan pinggiran pantai. Seiring berjalannya waktu dengan dibangunnya tempat-tempat usaha oleh investor maka terjadi perubahan dari segi sosial dan ekonomi masyarakat, namun ada juga masyarakat yang kehilangan pekerjaan, seperti nelayan.

\section{Karakteristik Responden}

\section{Jenis Kelamin}

Jenis kelamin berpengaruh terhadap aktivitas dan produktivitas manusia, dimana laki-laki mempunyai kemampuan fisik lebih baik jika dibandingkan dengan perempuan. Jenis kelamin menjadi ukuran dalam menentukan kemampuan sumberdaya suatu daerah atau wilayah dalam menentukan kemampuan daya saing. Pada Tabel 1 berikut dapat dilihat sebaran jenis kelamin sampel yang diambil di Kelurahan Wenang Selatan.

\begin{tabular}{llcc}
\multicolumn{4}{l}{ Tabel 1. Sebaran Jenis Kelamin Responden } \\
\hline No & Jenis Kelamin & Jumlah & Presentase (\%) \\
\hline 1 & Laki-laki & 12 & 40 \\
2 & Perempuan & 18 & 60 \\
\hline & Jumlah & 30 & 100
\end{tabular}

Sumber: Hasil Olahan (2018)
Berdasarkan Tabel 1 tersebut dapat dijelaskan bahwa sebaran jenis kelamin responden yang paling banyak adalah jenis kelamin laki-laki sebanyak 12 orang (40\%) sedangkan yang berjenis kelamin perempuan berjumlah 18 orang $(60 \%)$.

\section{Umur}

Umur merupakan salah satu faktor yang mempengaruhi produktivitas manusia yang biasanya diukur dalam satuan tahun. Pada tabel 2 berikut menunjukkan sebaran tentang umur responden dimana sebagian besar responden berada pada rentang usia 39-48 tahun yaitu sebanyak 9 orang $(30 \%)$, sedangkan presentasi terkecil yaitu pada usia 54-67 tahun sebanyak 5 orang (20). Berdasarkan tabel 2 tersebut maka dapat dikatakan bahwa sebagian responden berada pada usia produktif dn sampai pada waktu penelitian dilakukan mereka masih bekerja. Hanya sebagian kecil saja yang sudah dapat dikatakan tidak lagi muda atau tidak produktif.

Tabel 2. Sebaran Umur Responden

\begin{tabular}{llcc}
\hline No & Umur & Jumlah & Presentase $(\%)$ \\
\hline 1 & $29-38$ & 8 & 27 \\
2 & $39-48$ & 9 & 30 \\
3 & $49-53$ & 7 & 23 \\
4 & $54-67$ & 6 & 20 \\
\hline & Jumlah & 30 & 100 \\
\hline
\end{tabular}

Sumber: Hasil Olahan (2018)

\section{Tingkat Pendidikan}

Pendidikan merupakan kebutuhan manusia yang sangat penting dan harus menjadi bagian dalam proses kehidupan manusia yang harus dijalankan, karena dengan pendidikan akan mempengaruhi kualitas sumberdaya manusia baik untuk keluarga, masyarakat maupun negara.

Tabel 3. Sebaran Pendidikan Responden

\begin{tabular}{llcc}
\hline No & Pendidikan & Jumlah & Presentase (\%) \\
\hline 1 & SD & 1 & 3 \\
2 & SMP & 2 & 7 \\
3 & SMA & 13 & 43 \\
4 & SMK & 3 & 10 \\
5 & STM & 1 & 3 \\
6 & S1 & 8 & 27 \\
7 & S2 & 2 & 7 \\
\hline & Jumlah & 30 & 100 \\
\hline
\end{tabular}

Sumber: Hasil Olahan (2018) 
Sebaran pendidikan responden dalam penelitian ini berada pada jenjang SD sampai dengan S2, dimana tingkat pendidikan responden yang paling banyak adalah pada tingkat SMA dengan jumlah 13 orang (43\%), diikuti terbanyak kedua berada pada tingkat lulusan S1 yaitu sebanyak 8 orang (27\%), diikuti responden dengan lulusan strata dua (S2) dan lulusan SMP dengan jumlah yang sama yaitu masing-masing berjumlah 2 orang (7\%), sedangkan jumlah terkecil terdapat pada responden dengan lulusan STM dan lulusan SD, yaitu masing-masing berjumlah 1 orang (3\%).

\section{Pekerjaan}

Pekerjaan merupakan hal yang sangat penting bagi setiap orang, dimana dengan bekerja merupakan sarana guna mendapatkan penghasilan untuk memenuhi kebutuhan hidup terutama bagi yang sudah berkeluarga. Hal-hal yang berhubungan dengan kebutuhan tidak akan berhenti meski individu tersebut sudah tidak lagi produktif bekerja. Pekerjaan akan tergantung dari tingkat pendidikan, karena pendidikan juga merupakan salah satu kebutuhan dasar manusia yang diperlukan untuk menjalani kehidupannya, sehingga pendididikan dapat mempengaruhi kualitas seseorang dalam menjalankan pekerjaannya. Pada Tabel 4 berikut dijelaskan tentang sebaran perkerjaan responden.

\begin{tabular}{llcc}
\multicolumn{3}{l}{ Tabel 4. Sebaran Pekerjaan Responden } \\
\hline No & Pekerjaan utama & Jumlah & Presentase (\%) \\
\hline 1 & Satpam & 2 & 7 \\
2 & Nelayan & 1 & 3 \\
3 & Pedagang Ikan & 2 & 7 \\
4 & PNS & 3 & 10 \\
5 & Pensiunan & 3 & 10 \\
6 & Pensiunan Guru & 1 & 3 \\
7 & Swasta & 8 & 27 \\
8 & Wirawasta & 9 & 30 \\
9 & Dokter & 1 & 3 \\
\hline & Jumlah & 30 & 100 \\
\hline
\end{tabular}

Sumber: Hasil Olahan (2018)

Berdasarkan Tabel 4, dapat dijelaskan bahwa pekerjaan terbanyak dari responden adalah wiraswasta yaitu sebanyak 9 orang (30\%) diikuti sebagai swasta sebanyak 8 orang (27\%) diikuti oleh PNS dan pensiunan masingmasing sebanyak 3 orang (10\%), dan sebanyak
2 orang $(7 \%)$ sebagai satpam dan pedagang ikan, sedangkan pekerjaan responden yang paling sedikit adalah profesi nelayan, pensiunan guru dan dokter yaitu masing-masing sebanyak 1 orang $(3 \%)$.

\section{Dampak Pembangunan Kawasan Megamas}

Pembangunan merupakan suatu proses aktivititas yang dilakukan oleh pemerintah yang menunjukkan peningkatan kesejahteraan kehidupan bermasyarakat serta memberikan dampak lainnya seperti dampak sosial dan ekonomi. Pembangunan identik dengan pengurangan kemiskinan. Adanya peningkatan pembangunan akan sangat membantu untuk meningkatkan kesejahteraan msyarakat.

Suatu pembangunan akan berdampak terhadap kehidupan masyarakat, baik dampak positif maupun dampak negatif. Pada umumnya, beberapa dampak positif yang ditimbulkan seperti terciptanya lapangan pekerjaan yang dibutuhkan oleh masyarakat dan pengurangan pengangguran sehingga semakin meningkatkan kesejahteraan masyarakat. Namun demikian pembangunan juga akan memberikan dampak negatif seperti kerusakan lingkungan hidup.

\section{Dampak-dampak Negatif}

Tujuan suatu pembangunan yang dilakukan oleh pemerintah adalah untuk meningkatkan kesejahteraan masyarakat dalam berbagai aspek, yaitu sosial, ekonomi, maupun budaya. Dalam prosesnya, pembangunan akan selalu diupayakan akan memberikan dampak yang positif bagi kehidupan bermasyarakat, baik sejak awal pembangunan tersebut dimulai maupun setelah selesai. Namun demikian, setiap pembangunan akan memberikan dampak yang negatif.

Demikian halnya dengan pembangunan Kawasan Megas yang memberikan dampak baik dampak positif maupun dampak negatif. Berdasarkan Tabel 5, dapat dilihat bahwa terdapat 14 responden yang mengatakan bahwa pembangunan Megamas memberikan dampak yang negatif selain dampak yang positif. Tabel 
5 berikut menjelaskan tentang tanggapan masyarakat/responden terhadap dampakdampak negatif yang ditimbulkan akibat pembangunan Kawasan Megamas.

\begin{tabular}{llcc}
\multicolumn{3}{l}{ Tabel 5. Dampak-dampak Negatif } \\
\hline No & Kerugian & Jumlah & $\begin{array}{c}\text { Presentase } \\
(\%)\end{array}$ \\
\hline 1. & Konsumtif & 4 & 28 \\
2. & Keributan/tidak nyaman & 3 & 21 \\
3. & Kehilangan pekerjaan & 5 & 36 \\
4. & Kebersihan berkurang & 2 & 14 \\
\hline & $\quad$ Jumlah & 14 & 100 \\
\hline
\end{tabular}

Sumber: Hasil Olahan (2018)

Dalam hal dampak negatif yang dirasakan oleh masyarakat akibat pembangunan Kawasan Megamas (Tabel 5), sebanyak 5 responden (36\%) menyatakan bahwa mereka kehilangan pekerjaan. Dampak negatif lainnya yaitu mengalami konsumtif atau bertambahnya pengeluaran dan semakin tingginya keributan atau ketidaknyamanan masing-masing sebanyak 4 responden $(28 \%)$ dan terdapat 2 responden (14\%) yang mengatakan bahwa kebersihan lingkungan menjadi tidak bersih dan berkurang.

Tanggapan responden bahwa terjadinya penurunan pendapatan diakibatkan oleh kalah bersaingnya usaha-usaha yang dijalankan oleh masyarakat (terutama masyarakat yang berusaha warung dan dagang kecil-kecilan) akibat harga yang ditawarkan oleh beberapa supermarket cenderung lebih murah dibanding dengan yang mereka tawarkan. Masyarakat juga cenderung untuk berbelanja di kompleks pertokoan di Kawasan Megamas, karena mereka menilai tentang kelengkapan bahan, produk dan jasa yang ditawarkan.

Konsekuensi dengan adanya fasilitas yang lengkap dan menarik yang ditawarkan dengan adanya pembangunan kawasan Megamas adalah meningkatnya kecenderungan masyarakat untuk konsumtif, karena semakin meningkatnya frekuensi kunjungan masyarakat untuk datang ke tempat-tempat yang mempengaruhi keinginan masyarakat untuk berbelanja.

Dampak negatif lainnya adalah semakin meningkatnya tingkat kebisingan dan keributan akibat semakin banyak kendaraan dan semakin tingginya mobilitas orang (para pekerja). Hal ini menyebabkan keributan dan masyarakat merasa tidak nyaman karena dibandingkan dengan kondisi sebelum adanya kompleks Megamas, masyarat merasakan kehidupan yang tenang.

Tanggapan responden bahwa mereka kehilangan pekerjaan terutama pekerjaan utama yang sebelumnya sebagai nelayan. Profesi sebagai nelayan yang hanya sebagian besar berpendidikan rendah menyebabkan mereka kehilangan pekerjaan utamanya, karena ketika adanya kawasan tersebut, latar belakang pendidikan mereka tidak mampu terserap pada lapangan yang tersedia, walaupun sebenarnya ada beberapa rsponden menilai bahwa ada yang beberapa orang yang terserap pada sektor-sektor usaha yang tidak membutuhkan pendidikan tinggi (misalnya petugas keamanan).

Faktor kebersihan lingkungan yang berkurang menjadi salah satu faktor negatif yang ditimbulkan akibat adanya pembangunan kawasan Megamas. Hal ini terjadi karena responden menganggap bahwa semakin banyaknya penghuni dan pendatang mengakibatkan semakin banyak sampah, sedangkan pemerintah kurang menyediakan fasilitas tempat sampah. Kesadaran masyarakat terhadap proses untuk menjaga lingkungan menjadi tetap bersih belum menjadi bagian dari aktivitas kehidupan keseharian masyarakat.

\section{Dampak-dampak Positif yang Terjadi}

Proses pembangunan Kawasan Megamas, disamping memberikan dampak negatif, namun telah memberikan dampak positif bagi masyarakat di Kecamatan Wenang Selatan. Hal ini ditunjukkan dari tanggapan masyarakat (sebanyak 16 responden) bahwa pembangunan Kawasan Megas tersebut memberikan dampak postif.

Tabel 6 berikut dapat dijelaskan tentang beberapa manfaat atau dampak positif yang terjadi ketika adanya pembangunan kawasan Megamas.

Tabel 6. Dampak-dampak Positif yang Terjadi

\begin{tabular}{llcc}
\hline No & Dampak Postif/Manfaat & Jumlah & $\begin{array}{c}\text { Presentase } \\
(\%)\end{array}$ \\
\hline 1. & Peningkatan pendapatan & 4 & 25 \\
& dan kesejahteraan & & \\
2. & Penyerapan tenaga kerja & 5 & 31 \\
3. & Kesempatan berusaha & 4 & 25 \\
4. & Tempat Rekreasi & 3 & 19 \\
\hline & $\quad$ Jumlah & 16 & 100
\end{tabular}

Sumber: Hasil Olahan (2018) 
Pada Tabel 6 terlihat gambaran tentang tanggapan positif terhadap pembangunan Kawasan Megamas. Sebagian besar mengatakan bahwa dampak positif adalah terjadinya penyerapan tenaga kerja sebanyak 5 responden atau $31 . \%$ dan diikuti oleh dampak terjadinya peningkatan pendapatan dan kesejahteraan serta peningkatan pendapatan masing-masing sebanyak 4 responden (25\%) dan tersedianya tempat bagi masyarakat untuk berekreasi (tempat rekreasi) sebanyak 3 responden $(19 \%)$.

Faktor peningkatan pendapatan dan kesejahteraan dapat dijelaskan bahwa banyak masyarakat yang "mengalih-fungsikan" tempat tinggal keluarga untuk dijadikan tempat koskosan dan penginapan. Hal ini diakibatkan oleh semakin bertambahnya peningkatan permintaan tampat kos, karena sebagian besar pekerja yang bekerja di kompleks Megamall berasal dari luar daerah Kota Manado. Disamping itu juga, semakin banyaknya masyarakat yang membuka usaha-usaha kecil dalam bentuk rumah makan.

Semakin banyaknya jumlah usaha dalam bentuk pertokoan, menyebabkan sebanyaknya permintaan tenaga kerja sehingga terjadinya peningkatan penyerapan tenaga kerja. Walaupun sebagian besar pekerja yang bekerja berasal dari luar Kota Manado, namun banyak juga para pekerja yang berasal dari kelurahan yang bekerja di kompleks pertokoan Megamas.

Terbukanya lapangan usaha bagi masyarakat sekitar kawasanMegamas, dapat dilihat ketika banyak keluarga dan masyarakat yang membuka usaha kos-kosan, warung dan rumah makan serta masyarakat juga menilai bahwa pembangunan kawasan Megamas telah membuka akses untuk mendapatkan tempat rekreasi yang dekat dan murah.

\section{KESIMPULAN DAN SARAN}

\section{Kesimpulan}

Pembangunan Kawasan Megamas memberikan dampak baik dampak sosial maupun ekonomi, beruba dampak positif maupun negatif. Beberapa dampak postif yang ditimbulkan adalah peningkatan pendapatan dan kesejahteraaan, penyerapan tenaga kerja, adanya kesempatan berusaha dan tempat rekreasi, sedangkan dampak negatif adalah penurunan pendapatan, konsumtif, keributan/tidak nyaman, kehilangan pekerjaan dan kebersihan berkurang.

\section{Saran}

Perhatian pemerintah, pengusaha dan masyarakat harus ditingkatkan dalam suatu pembangunan seperti pembangunan Kawasan Megamas, karena memberikan dampak baik positif maupun negatif. Oleh karena itu, disarankan agar semua dampak negatif yang ditimbulkan dengan adanya pembangunan Kawasan Megamas bisa diperhatikan baik oleh pemerintah, pengusaha dan masyarakat agar dampak negatif tersebut tidak mempengaruhi kegiatan masyarakat. Sedangkan untuk semua dampak positif yang terjadi dapat ditingkatkan atau dipertahankan agar kelangsung hidup masyarakat lebih baik.

\section{DAFTAR PUSTAKA}

Hasni. 2010. Hukum Penataan Ruang dan Penatagunaan Tanah dalam Konteks UUPA-UUPR-UUPLH. Jakarta: Rajawali Pers.

Hudiyanto. 2005. Ekonomi Politik. PT Bumi Aksara Jakarta

Simarmata, Dj. A. 2012. Ekonomi Publik dan External, Ekonomi Tanpa Pasar. Fakultas Ekonomi Universitas Indonesia, Jakarta. 